\title{
The natural history of verb-stem reduplication in Bantu
}

\author{
Larry M. Hyman
}

Received: 2 January 2008 / Accepted: 2 March 2009 / Published online: 11 November 2009

(C) The Author(s) 2009. This article is published with open access at Springerlink.com

\begin{abstract}
In this study I present a comparative and historical analysis of "frequentative", Bantu verb-stem reduplication, many of whose variants have been described for a number of Eastern and Southern Bantu languages. While some languages have full-stem compounding, where the stem consists of the verb root plus any and all suffixes, others restrict the reduplicant to two syllables. Two questions are addressed: (i) What was the original nature of reduplication in ProtoBantu? (ii) What diachronic processes have led to the observed variation? I first consider evidence that the frequentative began as full-stem reduplication, which then became restricted either morphologically (by excluding inflectional and ultimately derivational suffixes) and/or phonologically (by imposing a bisyllabic maximum size constraint). I then turn to the opposite hypothesis and consider evidence and motivations for a conflicting tendency to rebuild full-stem reduplication from the partial reduplicant. I end by attempting to explain why the partial reduplicant is almost always preposed to the fuller base.
\end{abstract}

Keywords Partial reduplication · Bantu - Verb stem · Derivation · Inflection · Bisyllabic foot

\section{Introduction}

As Ashton (1944, p. 316) succinctly puts it, "REDUPLICATION is a characteristic of Bantu languages. It affects syllables, verb stems, words, and phrases.' Traditional Bantu grammars thus often include sections showing that verbs, nouns, adjectives,

L. M. Hyman ( $ه)$

Department of Linguistics, University of California, Berkeley, CA 94720-2650, USA

e-mail: hyman@berkeley.edu 
numerals and even pronouns and demonstratives can be reduplicated with specific semantic effects. In this, as in most aspects of Bantu grammar, the story is one of theme and variations: The reduplications in question show great similarity both in structure and in meaning, but also interesting differences. Nowhere are these differences more pronounced - or more significant - than in verb reduplication. While some Bantu languages exhibit total reduplication of the stem constituent consisting of the verb root + suffixes, others place maximum size constraints on the reduplicant and/or disallow certain suffixes, e.g. inflectional endings, from appearing within it. The major goal of this paper is to attempt to make sense out of this variation to determine the nature of verb reduplication in Proto-Bantu (PB). In order to do so, I start by cataloguing the various restrictions the ca. 500 daughter languages place on the reduplicant in Sect. 2. I then consider the possible relation of total reduplication to full word repetition in Sect. 3. In Sect. 4 I consider the evidence that the direction of change was from full-stem to partial-stem reduplication. While the simplest explanation is to assume, along with other scholars, that partial reduplication derives historically from full reduplication (Eulenberg 1971; Bybee et al. 1994; Niepokuj 1997), in Sect. 5 I present evidence that total verb-stem reduplication can be built up from partial reduplication. I therefore suggest in Sect. 6 that the changes have been bidirectional and conclude in Sect. 7 by addressing the question of why partial reduplicants develop on the left of the full base.

\section{Pan-Bantu verb-stem reduplication}

As is well known, Bantu languages have a highly agglutinative word structure. In order to appreciate the issues which arise in verb-stem reduplication, the traditional internal constituents of the verb in Proto-Bantu (PB) and most of the daughter languages are shown in (1), as reconstructed by Meeussen (1967):

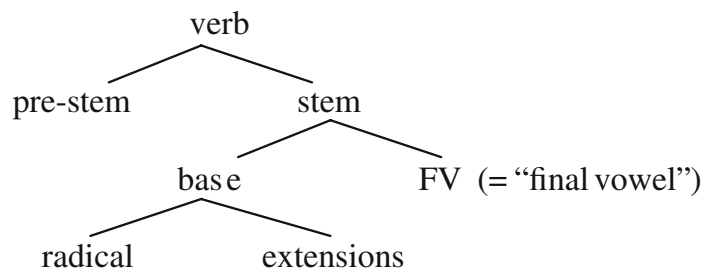

The different subconstituents are identified in (2), where some of the common PB suffixes are also indicated:

(2) a. pre-stem subject, negative, tense, aspect, object prefixes

b. radical verb root (-CVC- is the most common shape)

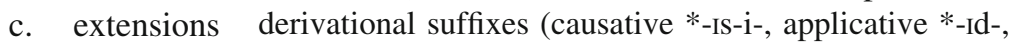

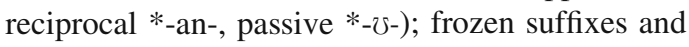
post-radical unanalyzable "expansions", 

d. FV
obligatory inflectional final suffix (past $*_{-I}$, subjunctive

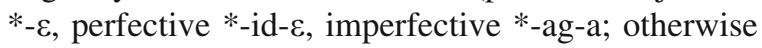 $\mathrm{FV}=$ default $*$-a)

An example from Haya is given in (3).

(3) ti- bá- ka- ki- [kóm]- el- angan- ag -a NEG-SUBJ-PAST-OBJ- tie- APPL-RECIP-HAB-FV 'they have never tied it for each other' (appl = applicative; $\mathrm{HAB}=$ habitual)

As seen, a Bantu verb can be quite long and involve both multiple prefixes and suffixes.

Given the structure of the Bantu verb in (1), three questions naturally arise. First, which morphological constituent in (4) was available for verb reduplication in PB?

(4) a. the whole word (prefixes + root + extensions + FV)

b. the verb stem (root + extensions $+\mathrm{FV})$

c. the verb base (root + extensions)

d. the verb root (perhaps with a linker vowel, e.g. CVC-a-CVC-a)

Besides the subconstituents of (1), there are other possibilities as well. As seen in the Haya example in (3), the object prefix (овJ) occurs closest to the verb stem. In some Bantu languages the OBJ+stem is has been treated as a "macro-stem" constituent for the purpose of tone assignment or, as we shall see, reduplication.

While the question in (4) concerns the morphological constituent which served as input to reduplication in $\mathrm{PB}$, i.e. which parts of the verb (prefixes, root, suffixes) could potentially be copied, a second question concerns the EXTENT of the reduplication: Could the constituent in question be fully copied, or was reduplication only partial? Not only do present-day Bantu languages differ from each other on this score, but there is even variation within the same language, as seen in the Tswana examples in (5), where reduplication marks the frequentative (Cole 1955, p. 217):

$$
\begin{aligned}
& \text { rék- } \varepsilon l-a \quad \text { 'buy for' } \rightarrow \text { a. rék- }-\varepsilon l-a+r \varepsilon k-\varepsilon l-a \quad \text { (H tone spreading } \\
& \text { buy-APPL-FV } \rightarrow \text { b. rék- } \varepsilon+\text { rek- }-\varepsilon l-a \text { not shown) } \\
& \rightarrow \text { c. rék-a + rek-el-a }
\end{aligned}
$$

While the full verb stem is reduplicated in (5a), only the first two syllables appear in the preposed reduplicant (RED) in (5b). (5c) shows that RED can also consist of a -CVC- verb root plus the linker vowel $-a$-. There is no difference in meaning between these three variants.

The final question concerns which part of the reduplicated word is the reduplicant? Particularly when reduplication is total it may not be immediately obvious whether the structure is RED-base or base-RED. In fact, three different structures appear to be needed, as in Tswana: 
(6) a. as in all verb stems, all but the first and last vowels of RED+stem are underlyingly toneless, including the second verb root, suggesting [ [ [ rék ] -el-a-rck- $\varepsilon l]$-a ]

b. segmental truncation occurs on first part, suggesting RED is preposed ("prefixed") to the base: [ [ rék- $\varepsilon$ ] [ rek-el-a ] ].

c. suffixes are often truncated, suggesting root reduplication: [ [ rék-a-rck ] -el-a ]

While it remains to be determined exactly what should be reconstructed, it is reasonable to assume that some kind of verb reduplication was present in PB. Certainly this is the impression one gets from the comparative and historical Bantu manuals. Meinhof (1932, p. 46) specifically refers to the kind of stem reduplication we are mostly concerned with here: "Complete and incomplete reduplication of the verb-stem occurs with an iterative-intensive force, e.g. Yao lava-lava 'go from place to place', from -lava 'start early in the morning', Swahili -cekaceka 'laugh continuously' from ceka 'laugh'.' Meeussen (1967, p. 88) also points out that Bantu languages often have lexicalized verb roots with $\mathrm{CV}$ - reduplications: "Some reconstructions... imply a type of radical with initial reduplication (-cvCVC-): -titim- 'be frightened', -tetem- 'tremble', -pepet- 'winnow', -tətom- 'tremble, quake, thunder'. The translations suggest meanings with a common element 'movement to and fro'.' The few lexicalized stem- or CV-reduplications present in the ca. 10,000 Bantu reconstructions in Bastin and Schadeberg (2003), generally have regional or infrequent attestations. Some examples are given in (7).

\begin{tabular}{|c|c|c|c|}
\hline *jág-a-jag- & 'be restless' & *jág- & $\begin{array}{l}\text { 'scratch, be cramped } \\
\text { for room' }\end{array}$ \\
\hline *díng-a-ding- & $\begin{array}{l}\text { 'wind round several } \\
\text { times or wrong' }\end{array}$ & *díng- & $\begin{array}{l}\text { 'twist, wrap up, } \\
\text { surround' }\end{array}$ \\
\hline *dé-demb- & 'swing, hang, float' & *démb- & $\begin{array}{l}\text { 'be hung up, hover, } \\
\text { swing' }\end{array}$ \\
\hline *mú-mun- & 'suck in mouth' & mon- & 'suck' \\
\hline
\end{tabular}

Still, the intuitive appeal of positing such a structure in PB derives from the fact that productive verb-stem reduplication is found with similar meanings in all Bantu zones. Representative examples are provided in (8).

(8) a. Duala (Cameroon): "to do something repeatedly without aim", (Meinhof 1912, p. 67); “a repeated (or frequent) and senseless action”, (Ittmann 1939, p. 195) ${ }^{1}$

$\begin{array}{llll}\text { tómb-a-tomb-ane } & \begin{array}{l}\text { 'pass by over and } \\ \text { over again' }\end{array} & \text { tómb-à } & \text { 'pass by' } \\ \text { yéng-a-yeng-ane } & \text { 'wander without aim' } & \text { yéng-a } & \text { 'walk' }\end{array}$

b. Gunu (Cameroon): "a continuous or sustained action"

(Rekanga 1989, p. 141)

\footnotetext{
1 The reciprocal suffix -ane is required in verb-stem reduplication in Duala.
} 


$\begin{array}{llll}\begin{array}{l}\text { bel-a-bel-a } \\ \text { námb-a-namb-a }\end{array} & \begin{array}{l}\text { 'lie continually' } \\ \text { 'prepare }\end{array} & \begin{array}{l}\text { bel-a } \\ \text { (continous action) }\end{array} & \text { 'lie' } \\ & & \end{array}$

c. Lingala (DRC): "a repeated... intensive... (or) futile action", (Guthrie 1939/1966, p. 37)

$\begin{array}{llll}\text { bét-a-bét-a } & \begin{array}{l}\text { 'give a good } \\ \text { beating to' }\end{array} & \text { bét-a } & \text { 'beat' } \\ \text { lob-a-lob-a } & \text { 'talk, chatter' } & \text { lob-a } & \text { 'speak' }\end{array}$

d. Nyanga (DRC): "an intensive value... do alot... several times", (Mateene 1969, p. 82)

$\begin{array}{llll}\text { i-kí-á-ki-a } & \text { 'faire et refaire sans cesse' } & \text { i-kí-a } & \text { 'faire' } \\ \text { i-bút-á-but-a } & \text { 'enfanter un peutrop' } & \text { i-bút-a } & \text { 'enfanter' }\end{array}$

e. Rimi (Tanzania): "frequency of action with... attenuation, purposelessness, errative', (Olson 1964, p. 161)

$\begin{array}{llll}\text { fing-á-fing-a } & \begin{array}{l}\text { 'trip, close } \\ \text { frequently' }\end{array} & \text { fing-a } & \text { 'trip, close' } \\ \text { mank-a-mank-a } & \text { 'trot' } & \text { mank-a } & \text { 'run' }\end{array}$

f. Mbukushu (Namibia): "frequency or intensification of an action", (Fisch 1998, p. 123)

$\begin{array}{llll}\text { korw-a-korw-a } & \text { 'always be sick' } & \text { korw-a } & \text { 'be sick' } \\ \text { kwat-a-kwat-a } & \text { 'touch everything' } & \text { kwat-a } & \text { 'touch' }\end{array}$

g. Yao (Mozambique): “'action... is realized repeatedly or frequently at large intervals" (Ngunga 2000, p. 107)
lim-a-lim-a
'cultivate frequently'
lim-a 'cultivate'
lokot-a-lokot-a 'pick up repeatedly'
lokot-a 'pick up'

h. Venda (South Africa): "an action that is carried out frequently or repetitively. Sometimes... aimlessly, or indiscriminately."

(Poulos 1990, pp. 195-6)

$\begin{array}{llll}\text { lim-a-lim-a } & \begin{array}{l}\text { 'plough sporadically } \\ \text { here and there' }\end{array} & \text { lim-a } & \text { 'plough' } \\ \text { dzul-a-dzul-a } & \text { 'sit here and there' } & \text { dzul-a } & \text { 'sit' }\end{array}$

By contrast, CV- reduplications are usually lexicalized, sometimes with an 'intrusive', $-l V$, as in Yao gala-gaat-a 'roll on the ground', yulu-yuund-a 'scrape out' kolo-koosol-a 'shell' (Ngunga 2000, p. 114). While it is not clear whether the two reduplicative patterns are historically related, doublets do appear in some languages, e.g. in Kinyarwanda: ku-béera-beera ku-bé-beera 'to walk aimlessly', ku-búutabuuta ku-búu-buuta 'to walk back bent' (Kimenyi 2002, p. 260). The shared property that can be isolated throughout Bantu is that verb reduplication primarily or only targets the stem. As we shall see, prefixal material only sporadically makes it into RED, and only when motivated by phonological constraints. Although there is some question about whether the pre-stem elements were prefixes or separate clitics or words in Proto-Bantu (see Hyman 2007; Nurse 2007), it is clear that they ARE prefixes in many Bantu languages, e.g. in Luganda (Hyman and Katamba 2005). Thus, the general exclusion of prefixes in reduplication could have one of two 
diachronic explanations: First, if Meeussen's reconstruction in (1) is correct, reduplication may have originally targeted a sub-constituent of the verb in $(4 b-d)$. Alternatively, if the pre-stem markers were not prefixes at the time verb reduplication was introduced, they would have automatically been excluded. However, we would have to add that once these markers became prefixes, the question would be why they did not later become incorporated into RED. This second explanation most naturally fits the claimed universal that reduplication always begins as total copy and that changes follow the universally unidirectional process of full $>$ partial reduplication (Niepokuj 1997). In the next section I consider the logic and evidence for full verb reduplication in PB.

\section{Reduplication versus repetition}

To recapitulate, and setting aside the issue of the macro-stem for the moment, we are considering four hypotheses concerning the origin of verb reduplication in Bantu:

(9) a. PB reduplication targeted the whole verb (prefixes + root + extensions $+\mathrm{FV}$ )

b. PB reduplication targeted the verb stem (root + extensions $+\mathrm{FV}$ )

c. $\mathrm{PB}$ reduplication targeted the verb base (root + extensions)

d. PB reduplication targeted the verb root only (e.g. -CVC-a-CVC-)

There are several intuitive arguments for whole-verb reduplication, both universal and Bantu-specific. First, there is the possibility of deriving reduplication from word repetition, as in You talk, talk, talk all the time! Second, there is the possibility of maintaining unidirectionalitiy, i.e. *full > partial reduplication (Niepokuj 1997). Third, there is synchronic evidence that at least some cases of partial reduplication should be treated as "morphological doubling", (Inkelas and Zoll 2005; cf. Steriade 1988). As Eulenberg (1971, p. 73) puts it, “. ..cases of so-called partial reduplication are simply phonological [and morphological] reductions, sometimes drastic, from cases of full reduplications."

Concerning the possible diachronic process repetition $>$ reduplication, many Bantu languages are known for repeating full words and phrases in spontaneous discourse. Examples from Totela are provided in (10) (Thera Crane, personal communication):
a. Abo ba-ku-tutuluka ku-kula ku-kula muzi
they they-NARR-come. out NARR-clean NARR-clean village
ku-kula muzi 'They came out and cleaned up NARR-CLEAN village the whole village.'

b. Ku-mu-busa-busa ku-mu-busa-busa ba-ku-mu-ta NARR-her-greet-greet NARR-her-greet-greet they-NARR-her-tell 'They greeted her (enthusiastically, over and over) and they told her...' 
While there is an obvious semantic link between repetition, as in the above examples, and the frequentative meanings seen in the examples in (8), there are potential differences. Fortune (1982, p. 49), for example, states that "the meaning of the reduplicated $\mathrm{R}$ differs from that of the R repeated,' providing examples such as the following from Shona: Róvá! Róva!! 'Hit! Hit!' versus Róv-á-róv-a 'hit all over indiscriminately!'. In the first case each verb gets its own tonal assignment, while in the second, there is a single tone assignment over the whole verb.

Once we leave the verb, we find that there are widespread cases of full word reduplication (or is it "repetition"?), for example, the widespread distributive numeral construction exemplied in (11) from Kanyok, which drops final vowels (Mukash-Kalel 1982, p. 151):

$$
\begin{array}{llll}
\text { a. bà-bìdy 'two' } \rightarrow & \text { bà-bìdy bà-bìdy } & \text { 'two by two, two each' } \\
\text { b. bà-sàt 'three' } \rightarrow & \text { bà-sàt bà-sàt } & \text { 'three by three, three each' }
\end{array}
$$

As seen, the class 2 plural prefix $b a$ - is copied along with the numeral stem. I am unaware of any Bantu language which allows forms like *bà-bìdy-bìdy and *bà-sàt-sàt.

Even the reduplication of nouns and adjectives is more amenable to allowing a prefix to be copied into the reduplicant. In Kinande, noun reduplication assigns meanings like 'a real X' or 'a good example of an X' versus. other Bantu languages where the meaning would be pejorative (e.g. 'a lousy example of an X'). As seen in (12a), a noun prefix will not be copied if the stem is bisyllabic, which also establishes that RED is postposed to the base (Mutaka and Hyman 1990, pp. 77-80): ${ }^{2}$

\begin{tabular}{|c|c|c|c|}
\hline kv-g $v l v$ & 'leg' & $\rightarrow$ & 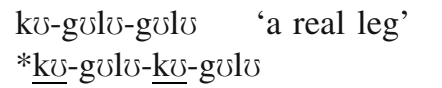 \\
\hline mớ-síka & 'girl' & $\rightarrow$ & $\begin{array}{l}\text { mớ-síka-síka 'a real girl' } \\
\text { *mứs-síkà-mớ-síkà }\end{array}$ \\
\hline ká-tı & 'stick' & $\rightarrow$ & 'a real stick' \\
\hline ri-bwe & 'stone' & $\rightarrow$ & ri-bwe-ri-bwe \\
\hline ḿ-b $\mho s l i$ & 'goat' & $\rightarrow$ & ḿ-bəslí-m-bəsli \\
\hline ń-zoka & 'snake' & $\rightarrow$ & ń-zoká-n-zoka \\
\hline mú-heruki & 'bride' & $\rightarrow$ & *mú-heruki-heruki \\
\hline ki-témbekali & 'tree (sp.)' & $\rightarrow$ & *ki-témbekali-témbekali \\
\hline
\end{tabular}

In (12b), however, the prefix is copied when the stem is monosyllabic, as it is in (12c), where the nasal is non-syllabic, unless initial. The generalization is that Kinande requires a bisyllabic RED: either the stem in (12a) or the prefix + stem in $(12 b, c) .(12 d)$ shows that longer stems cannot be reduplicated. If the full stem were reduplicated, RED would have three or four syllables. Truncated solutions such as *mú-heruki-heru or *mú-heruki-ruki are not acceptable because of MORPHEME INTEGRITY: Kinande prohibits the mapping only part of a morpheme into RED.

\footnotetext{
${ }^{2}$ Unlike verb reduplication, tones are copied in noun reduplication in Kinande and generally in Bantu. The Kinande forms are cited without final boundary tones.
} 
The same RED $=\sigma-\sigma$ is in force in Kinande verb reduplication, but with a crucial difference. As seen in (13a), where the verb stem is monosyllabic, the noun class 5 infinitive prefix $r$ - cannot be copied into RED as was possible in the case of nouns in $(12 b)$.
a. rI-sw-a 'to grind' $\rightarrow$ (ri-) swa-swa + sw-a '... a little here and there' rí-tw-a 'to cut' $\rightarrow$ (rí-) twa-twa + tw-a
b. rI-hom-a 'to beat' $\rightarrow$ (rI-) h $\mho$ m-a + hrm-a
rí-trsm-a 'to send' $\rightarrow$ (rí-) trsm-a + trsm-a
c. ri-hrm-Ir-a 'to beat for/at' $\rightarrow$ (rI-) h $s \mathrm{~m}-\mathrm{a}+\mathrm{h} \gamma \mathrm{m}-\mathrm{Ir}-\mathrm{a}$

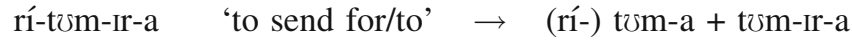

As a result, the verb stem must copy twice in order to fill out the bisyllabic RED requirement. The bisyllabic stem reduplicates as expected in (13b), whereas reduplication is possible in (13c) only because the applicative suffix -Ir-can be truncated. As will be seen in the following sections, similar "complications" are observed in other Bantu languages. In Sects. 4 and 5 we consider two hypotheses: first, that $\mathrm{PB}$ had full verb-stem reduplication which has been subject to truncations, and second, that $\mathrm{PB}$ had verb-root reduplication which has been subject to augmentations.

\section{Hypothesis I: full > partial verb-stem reduplication}

Despite the semantic and structural similarities of verb reduplication within Bantu, there are important formal differences in the phonological size of preposed RED and its morphological contents. First, it should be noted that some Bantu languages require full verb-stem reduplication. As seen in the Ciyao examples in (14) (Ngunga 2000, pp. 105-107), both derivational extensions such as applicative -il-/-el- and final inflectional endings such as perfective -il-e are reduplicated. (Reduplications are shown without prefix morphemes, since these latter do not copy.)

$$
\begin{array}{llll}
\text { a. } \operatorname{root}+-\mathrm{a} & : \text { telek-a } \rightarrow \begin{array}{l}
\text { telek-a }+ \text { telek-a } \\
\text { 'cook frequently' }
\end{array} \\
\text { b. root-APPL-a }: \text { telec-el-a } \rightarrow \begin{array}{l}
\text { telec-el-a }+ \text { telec-el-a } \\
\text { 'cook for (s.o.) frequently' }
\end{array} & \\
\text { c. root-PERF }: \text { dim-il-e } \rightarrow \begin{array}{l}
\text { dim-il-e }+ \text { dim-il-e } \\
\text { 'cultivated many times' }
\end{array}
\end{array}
$$

While languages like Ciyao and Luganda must fully reduplicate the verb stem, truncation of suffixes in RED is quite widespread. As seen in (15), Odden (1996, pp. 130-145) has caught Kikerewe in transition: 
(15) a. ku-lim-il-an-a 'to cultivate for each other'

i. ku-lim-il-an-a + lim-il-an-a (full stem reduplication)

ii. ku-lim-il-a + lim-il-an-a (reciprocal -an- is "truncated")

iii. ku-lim-a + lim-il-an-a

(applicative -il- and reciprocal -an-

are truncated)

iv. *ku-lim-an-a + lim-il-an-a (applicative -il- truncated)

b. a-lim-íl-é 'he cultivated'

i. a-lim-il-e + lim-íl-é

ii. a-lim-a + lim-íl-é

(full stem reduplication)

(inflectional -ile is "truncated",

$$
-\mathrm{a}=\text { default) }
$$

c. ku-káláang-a 'to fry'

i. ku-kálááng-a + kalaang-a 'to fry any old way'

ii. *ku-kálá + kalaang-a (full root must reduplicate)

Full verb stem reduplication is shown in the (i) examples. In (15a.ii) the first of the two derivational extensions has been truncated, while (15a.iii) has truncated both. The ungrammatical form in (15a.iv) shows that it is not possible to truncate the second extension (reciprocal -an-) without truncating the first, i.e. once an input suffix has failed to be copied in RED, no suffixes to its right can be further considered. The relevant constraint is that "the reduplicant must correspond to a contiguous substring of the derivational [i.e. base] stem"' (Odden 1996, p. 137). (15b.i.) again shows full reduplication, this time including the perfective ending -il-e, which however can be truncated, as in (15b.ii), where RED appears with the default FV -a. (15c.i.) exemplifies the full reduplication of a long verb root, while (15c.ii) shows that truncation is not possible if the result is a violation of morpheme integrity: "partial copying of morphemes is blocked" (Odden 1996, p. 138).

Thus far we have established two tendencies that contribute to RED being less than total reduplication: the tendency for RED to consist of two syllables and the tendency for RED to exclude suffixal material (other than the default FV - $a$ ). Concerning the first, there actually are three different situations, depending on whether the twosyllable RED is (i) a minimum, (ii) a maximum, or (iii) both. As seen in (16), which shows reflexes of stems containing the PB roots $*_{-} g \mho-$ 'fall' and *-dim'cultivate', all three situations are attested:

$$
\begin{aligned}
& \text { (i) } \operatorname{RED} \geq \sigma-\sigma \\
& \text { (ii) } \operatorname{RED} \geq \sigma-\sigma \\
& \text { e.g. Sukuma } \\
& \text { e.g. Kinyarwanda } \\
& \text { gw-a-gw-a + gw-a } \\
& \text { gw-aa + gw-aan-a } \\
& \text { 'fall here \& there' } \\
& \text { lim-Il-a + lim-Il-a rim-aa + rim-ir-a } \\
& \text { 'cultivate for here \& there' }
\end{aligned}
$$

(i) In Sukuma, RED "is not maximally disyllabic although minimally it must be at least disyllabic', (Matondo 2003, p. 133). As seen, RED may doubly reduplicate a monosyllabic stem in order to fill out the two-syllable minimum. An 
alternative is to copy a preceding prefix, e.g. (gv-) $g w-a-g w-a+g w-$ $a \sim g \mho-g w-a+g v-g w-a$ 'to fall here \& there' (Matondo 2003, p. 122). There is no upper limit on the size of RED, e.g. leembeel-el-nij-iw-a+ leembeel-el-nij-iw-a ('be calm' + APPLICATIVE + Simultaneous + PASSIVE). However, when a verb stem contains only one productive suffix, it may optionally be truncated, e.g. lim-Il-a + lim-Il-a $\sim$ lim-a + lim-Il-a 'cultivate for here \& there' (Matondo 2003, pp. 129-130, 154).

(ii) Kinyarwanda is unusual both in limiting RED to root material only and in its treatment of subminimal -CV- roots. While Kimenyi (2002) shows that /gu-a/ $g w-a$ 'fall' cannot reduplicate as $* g w-a a+g w a$, Fidèle Mpiranya (personal communication) points out that it is possible for $g w-a$ to reduplicate as $g w-a a+g w$-aan- $a$, where the base has been augmented by what looks like the reciprocal extension -an- (cf. /pfu-a/pf- $a$ 'die' $\rightarrow p f-a a+p f$ aan- $a$ 'waste away', i.e. 'die a little bit here and there'). ${ }^{3}$ As a result, RED can be either monosyllabic or bisyllabic in Kinyarwanda.

(iii) The third situation is the most common and is represented by Ndebele, which has an absolute requirement that RED consist of two syllables. When the stem is monosyllabic, a dummy second syllable $-y i$ thus fills out the bisyllabic template.

While the tendency towards a bisyllabic RED is a phonological condition, it sometimes goes hand in hand with the second tendency to exclude both extensions and inflectional endings other than default $-a$. The additional examples in (17) show that Ndebele's bisyllabic RED does not respect morpheme integrity (Hyman et al. 2009):
a. lim-a
'cultivate'
$\rightarrow \quad \lim -\mathrm{a}+\lim -\mathrm{a}$ '... a little here and
$\rightarrow$ thum-a + thum-a there'
b. nambith-a 'taste'
$\rightarrow$ nambi + nambith-a
thembuz-a 'go from wife to wife' $\rightarrow$ thembu + thembuz-a

Long roots therefore can be truncated, as in (17b). When the verb root occurs with a productive derivational extension, RED occurs in two forms, as in (18).
a. lim-el-a $\rightarrow$ lim-e + lim-el-a
'cultivate for/at'
(applicative -el-)
b. $\quad \lim -\mathrm{is}-\mathrm{a} \rightarrow \lim -\mathrm{i}+$ lim-is-a
'make cultivate' (causative -is-)
$\rightarrow \quad$ lim-a + lim-is-a

\footnotetext{
${ }^{3}$ One is reminded of the obligatory suffixation of reciprocal -ane in Duala reduplication seen in (8a). Reciprocal -an- is also sometimes added to convert a monosyllabic stem into a bisyllabic word, as in the singular affirmative imperative in Ndebele: /m-a/ 'stand' $\rightarrow m$-an- $a$ (Sibanda 2004) with the variant yi-ma (Downing 2001, p. 36).
} 
Either the first vowel of the -VC- extension is copied, or the extension is truncated and default $-a$ appears instead. However, although (17b) and the first variants of $(18 \mathrm{a}, \mathrm{b})$ show that Ndebele does not respect morpheme integrity, monomorphemic verb bases of $3+$ syllables still cannot reduplicate with - $a$ : *namb-a + nambith- $a$, *themb-a + thembuz- $a$. The generalization is that replacement by default $-a$ is possible only if all of the root material has been exhaustively mapped into RED.

While the first variants of $(18 \mathrm{a}, \mathrm{b})$ show that the vowel of a derivational suffix can be copied into RED, (19) shows that RED cannot contain inflectional material from the base:
a. lim-e $\rightarrow$ lim-a + lim-e
$* \lim -\mathrm{e}+$ lim-e
(subjunctive -e)
b. $\lim -\mathrm{i} \rightarrow \lim -\mathrm{a}+\lim -\mathrm{i}$
$* \lim -\mathrm{i}+\lim -\mathrm{i}$
(negative -i)
c. lim-ile $\rightarrow$ lim-a + lim-ile
*lim-i + lim-ile
(perfective -ile)

As observed, default $-a$ is required to fill out the bisyllabic RED in such cases.

In (20) I summarize the properties of Ndebele RED in terms of the Bantu verb stem according to Downing (1999, 2003):

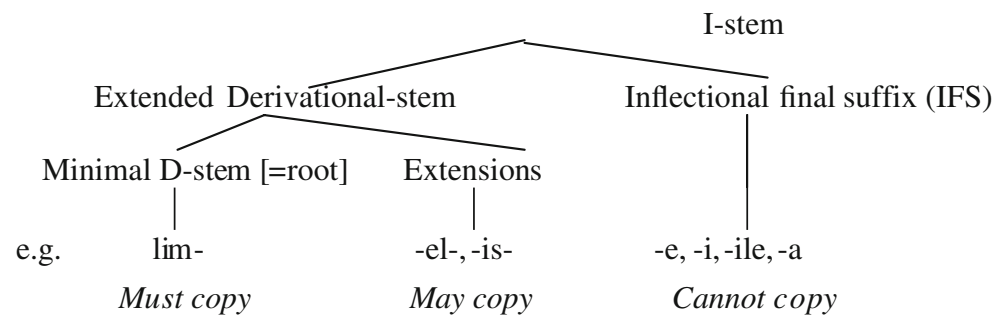

What these examples show is that there are Two scales for paring down the reduplicant, starting with the full (inflected) verb stem, as in (21).
a. Phonological scale: full $>$ foot $(\sigma-\sigma)>$ syllable
$(>$ mora $>$ tone $>\varnothing)$
b. Morphological scale: I-stem $>$ Extended D-stem $>$ root

Concerning the morphological scale, Ndebele nicely captures the three-way distinction: All root material for which there is room is obligatory in RED, derivational material is optional, and inflectional material is prohibited. A logical extension of this is to restrict reduplication to CVC- roots, as is nearly the case in Kinyarwanda. Since Kimenyi's (2002) study mostly concerns lexicalized verb-stem reduplication, in (22) I have replaced his examples with relatively productive ones provided by Fidèle Mpiranyi (personal communication) to show that non-syllabic extensions such as passive /-u-/ $-w$ - and causative / $/ \mathrm{i}-/-y$ - do not occur in RED even if there is room for them: ${ }^{4}$

\footnotetext{
${ }^{4}$ In (22b), $r \rightarrow z$ before causative $-i$-. Mpiranya points out that there are lexicalized exceptions where the causative is copied: rwáar-a 'be sick' $\rightarrow$ /rwaar-i-a/ rwáaz-a 'take care of a sick person' $\rightarrow$ rwáaz$a+$ rwáaz- $a$ 'take care of a sick person or situation with a lot of effort'.
} 
(22)
a. rim-w-a 'be cultivated' $\rightarrow$ rim-aa + rim-w-a 'be cultivated
b. kwiiz-a 'spread (tr.)' $\rightarrow$ kwíir-a + kwiiz-a /kwiir-i-a/
(*kwiiz-a + kwiiz-a)
cf.kwiir-a 'spread (intr.) $\rightarrow$ kwiir-a + kwiir-a
several times' 'spread (tr.)
all over' 'spread (intr.)
all over'

It does, however, seem at least marginally acceptable for a productive -VCextension to appear with a CV- root in RED, e.g. $g w$-iir-a 'fall for/at' $\rightarrow$ gw-iir$a+g w$-iir- $a$, gu-ush- $a$ 'cause to fall' $\rightarrow g u-u s h-a+g u-u s h-a$. While Kinyarwanda does not allow reduplication of unanalyzable stems of three or more syllables, or those whose morphology is frozen or unproductive, Kikuyu has imposed Downing's (1999) canonical CVC-a stem in defiance of morpheme integrity (Peng 1991; Mugane 1997, p. 12):
kor-a
cin-a
'grow'
$\rightarrow$ kor-a + kor-a
'burn'
$\rightarrow$ cin-a + cin-a
b. koor-a
'pull out'
$\rightarrow$ koor-a + koor-a
ßuut-a
'depose'
$\rightarrow$ Buut-a + Buut-a
c. Bocor-a

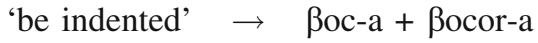
d. ciãerer-a
'be quiet'
$\rightarrow$ həor-a + hoorer-a
hwererck-a
'encircle'
$\rightarrow$ ciã-a + ciãerer-a
$\rightarrow$ hwer-a + hwererek-a

Neither Kinyarwanda nor Kikuyu allow inflectional endings in RED.

Concerning the phonological scale in (21a), we have yet to illustrate the reduction to a syllable. As seen in (24), Lengola expresses the habitual by means of verb-stem reduplication (Stappers 1971, p. 268):
a. i-kul-a 'acheter' i-kul-a + kul-a
i-6on-a 'regarder' i-bon-a + bon-a
i-túm-a 'envoyer' i-túm-a + tum-a
i-límb-a 'chanter' i-límb-a + limb-a
$(\mathrm{CVC}-\mathrm{a} \rightarrow \mathrm{CVC}-\mathrm{a}$ reduplication)

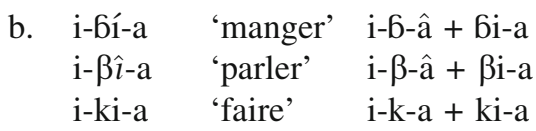
c. i-kpet-a 'couper' i-kp-a + kpet-a (CVC-a $\rightarrow$ C-a- reduplication)
i-gbok-a 'trouver' i-gb-a + gbok-a
i- $\phi a ́ m-a$ 'crier' i- $\phi$-â $+\phi a m-a$
$(\mathrm{CV}-\mathrm{a} \rightarrow \mathrm{Ca}-$ reduplication $)$ 
As seen, the -CVC- verb roots in (24a) fully reduplicate along with the FV $-a$. In (24b), where the root has the shape -Ci-, the vowel is truncated in RED. The forms in (24c) show that the RED of some -CVC- roots has also been truncated to $C-a$-.

A similar story comes from Kanyok, which contrasts stem- and CV- reduplication (Stappers 1986a, p. 17; Mukash-Kalel 1982, pp. 151-2, personal communication):

a. frequentative: 'tout le temps et de manière désordonnée',

$\operatorname{dim}$ 'cultiver' $\rightarrow \operatorname{dim}+\operatorname{dim} \quad$ ow 'se laver' $\rightarrow$ ow + ow

tum 'envoyer' $\rightarrow$ tum + tum and 'creuser' $\rightarrow$ and + and

b. imperfective aspect (progressive, durative)

$\operatorname{dim}$ 'cultiver' $\rightarrow$ dii $+\operatorname{dim} \quad$ ow 'se laver' $\rightarrow$ ow + ow

tum 'envoyer' $\rightarrow$ tuu + tum and 'creuser' $\rightarrow$ and + and

Since Kanyok has lost most final vowels, the frequentative forms dim-dim and tumtum in (25a) are equivalent to dim- $a+d i m-a$ and tum- $a+t u m-a$ in other Bantu languages. In (25b), we see that CVC roots have a CVV- RED in the imperfective aspect. Both Lengola and Kanyok thus exploit stem reduplication for marking aspect. While the two RED patterns may at first seem unrelated, there is, in turn, an obvious semantic relation between frequentative 'allthe time, here and there' and imperfective aspect. I hypothesize, therefore, that both constructions in (25) have the same source. This is confirmed in the case of - VC- roots. As seen in the right column of $(25 \mathrm{a}, \mathrm{b})$, the frequentative and imperfective have the same reduplicated root-and there is no vowel lengthening in the imperfective (i.e. *oow-ow). We might hypothesize that the frequentative originally imposed a two-syllable minimum on RED. This constraint was subsequently relaxed in the semantic split that gave rise to the reduplicated imperfective aspect (which is clearly an innovation). Further evidence is seen from the ways in which subminimal -CVroots reduplicate in (26).

$$
\begin{aligned}
& \text { a. /tu/ tw 'piler' } \rightarrow \text { tw-aa-tw-aa-tw } \\
& \text { b. }
\end{aligned}
$$

As seen, the historical FV - $a$ appears (lengthened) in RED, which in the frequentative can optionally produce a triplicated structure. Both the total reduplication of -VCroots and the presence of - $a a$ - suggest that the RED of imperfective CVV-reduplication was originally *CVC-a.

The change of $* \mathrm{CVC}$-a to $\mathrm{CV}$ - reduplication is also seen in Boma nominalized habituals, which Stappers (1986b, p. 40) describes as having an implied pejorative sense. Thus, when habitual/repetitive verb forms such as in (27a) are nominalized, RED develops into a consonant + high vowel, as in (27b).

$$
\begin{aligned}
& \text { a. laь-á } \rightarrow \text { аав-а-laь-á 'usually/always go on walks' } \\
& \text { b. sás-a } \rightarrow \text { i-š̌-sáb-a 'customary doing' } \\
& \text { za:в- } \varepsilon \rightarrow \text { i-zi-za:ь- } \varepsilon \quad \text { 'customary eating' } \\
& \text { cûm-a } \rightarrow \text { i-cǔ-cûm-a 'customary buying' }
\end{aligned}
$$




$$
\begin{aligned}
& \text { kwân-a } \rightarrow \text { i-kǔ-kwân-a 'customary loving' } \\
& \text { kób-a } \rightarrow \text { i-kǔ-kób-a 'customary weaving' }
\end{aligned}
$$

While attested only in Northwest Bantu, $\mathrm{Ci}-/ \mathrm{Cu}$ - reduplication is of course wellknown from West Africa. ${ }^{5}$ Further reduction of a single-syllable RED is seen in (28) from Bafia, another Northwest Bantu language (Aroga Bessong and Melcuk 1983, p. 500):

$\begin{array}{llll}\text { infinitive } & & \begin{array}{l}\text { 3sg + durative } \\ \text { reduplication }\end{array} & \begin{array}{l}\text { RED } \rightarrow \varnothing \text {, with } \\ \text { V length }\end{array} \\ \text { ri-kàn } & \text { 'écrire' } & \text { á-kày-kàn } & \text { â:-1kàn } \\ \text { rí-sòo } & \text { 'laver' } & \text { á-sòo-sòo } & \text { â:-sòo } \\ \text { ri-kálí } & \text { 'dire' } & \text { á-'ká-kálí } & \text { â:-kálá } \\ \text { ri-lànf́ } & \text { 'se fendre' } & \text { á-là-lànf́ } & \text { â:-làní }\end{array}$

As seen, durative reduplication is marked by a monosyllabic RED. As an alternative, RED may undergo segmental deletion, which Aroga Bessong and Melcuk term "contraction". In the last column of (28) we see that the subject acquires the low tone of the RED to become a high-low falling tone on a long vowel. If this contraction replaced the earlier construction, there would be no synchronic evidence that the durative had originally involved reduplication rather than the loss of an aspectual (C)V prefix with low tone. The last steps in the phonological evolution of reduplication are, thus, reanalysis and loss.

\section{Hypothesis II: partial > full verb-stem reduplication}

In the previous section we saw that some Bantu languages have full-stem verb reduplication, while others reduplicate less than the full stem. In some cases the truncations or "contraction" are clear innovations and look rather recent. The simplest hypothesis is that PB reduplicated the full verb stem, which was later pared down to morphologically and phonologically simpler structures. Hypothesis I thus claims a unidirectionality from a bigger to a smaller RED. The full story is, however, a bit more complex. There are counter-tendencies which can have the effect of ENLARGING the reduplicant, i.e. in going from a smaller to a bigger RED (cf. Hurch and Mattes 2005). If correct, this would mean that there has been bidirectional change, which naturally could complicate the task of determining what the PB situation in fact was.

\footnotetext{
${ }^{5}$ Stappers doesn't give enough examples to be certain, but except for $i-k u ̆-k a ̂ n-a$ 'customaryplanting', the $\mathrm{Cu}$ - RED occurs when the root either has a round vowel or begins with $\mathrm{Cw}$. On the other hand, roots with a $C i$ - RED have both an initial coronal consonant and the vowel $/ \mathrm{a} /$ or $/ \varepsilon /$.
} 
As I shall now document, these counter-tendencies take the following shapes:
a. RED may include affixes (which are otherwise barred) to make RED bisyllabic
b. RED may include affixes (which are otherwise barred) because they syllabify with the root
c. RED may include affixes (which are otherwise barred) when base-reduplicant featural non-identity would otherwise result

As we shall see, the result is that RED may be enlarged in one of two ways: First, more stem material, specifically suffixes, may become incorporated into RED. Second, material outside the stem, specifically prefixes, may become incorporated into RED. Whereas the first has to do with how much of the verb stem is copied in reduplication, the second has to do with the scope of reduplication and whether it can "see" prefixal material lying to the left of the stem. In the following subsections we will focus first on the issue of prefix-incorporation into RED and then consider cases where inflectional suffixes are exceptionally copied.

\subsection{Prefix-incorporation}

The first situation to be considered is when a prefix is exceptionally copied when it is needed to make RED bisyllabic. This happens only in the case of sub-minimal verb roots, which are either /-CV-/ or /-C-/, depending on the language. In (30) we see how the subminimal root $-d l$ - 'eat' is reduplicated in Ndebele:

$$
\begin{aligned}
& \text { a. (úku-) dl-a 'to eat' } \rightarrow \text { (ú-ku-) dla-yi + dla } \\
& \text { b. (úku-) zi-dl-a 'to eat them' } \rightarrow \text { (ú-ku-zi-) dla-yi + dla } \\
& \text { c. (úku-) zi-dl-a 'to eat them' } \rightarrow \text { (ú-ku-) zi-dla + zi-dla } \\
& \text { d. (úku-) zi-bón-a 'to see them' } \rightarrow \text { (ú-ku-zi-) bón-a }+ \text { bon-a } \\
& \text { *(ú-ku-) zi-bó(n-a) + zi-bon-a }
\end{aligned}
$$

In (30a), the verb stem $d l$ - $a$ 'eat' is monosyllabic. Recall that Ndebele requires a bisyllabic RED. In order to fill out the template, a dummy syllable $-y i$ is added to the monosyllabic stem. Since the class 15 augment + prefix sequence /ú-ku-/ is not available, (30a) represents the only way that subminimal $d l$ - $a$ can be reduplicated. The same dla-yi RED is observed in (30b), where the class 10 object prefix $z i$ - 'them' has been added. However, (30c) shows that zi- may alternatively be itself reduplicated. What this means is that when another syllable is required, Ndebele speakers can "go up" to the macro-stem level, the constituent which consists of the object prefix + stem. As seen in (30d), this strategy is not available if the root is any longer, i.e. if it is -CVC-. If $z i$ - is included, the resulting RED will violate one of two otherwise inviolable constraints: (i) *zi-bón$a+z i$-bon- $a$ has a trisyllabic RED; (ii) *zi-bó $+z i$-bon- $a$ has a RED which fails to parse as much of the root as possible, specifically the /n/ of /-bón-/ 'see'.

As we saw with respect to suffixal material, an object prefix can appear in RED only if the root material is exhausted. The five equally acceptable outputs in (31), all 
of which derive from $u$ - $k u$-zi-dl-el-a 'to eat them for/at', show that an object prefix may appear in RED even if an extension occurs with the consonantal root:
a. (ú-ku-zi-) dl-el-a $\rightarrow$ (ú-ku-zi-)
dl-el-a + dl-el-a eat-APPL-FV $\rightarrow$ (ú-ku-zi-)
dl-a-yi + dl-el-a
b. (ú-ku-) zi-dl-el-a $\rightarrow$ (ú-ku-zi-)
dl-e-yi + dl-el-a
OBJ-EAT-APPL-FV $\rightarrow$ (ú-ku-)
zi-dl-a + zi-dl-el-a
zi-dl-e + zi-dl-el-a

In (31a), where reduplication occurs at the stem level, there are three different possibilities. First, the full stem $\mathrm{dl}$-el-a 'eat for/at' can be copied. Second, the applicative extension - $e l$ - can be truncated, in which the reduplicant consists of the root + default FV $-a(d l-a)$ plus the dummy syllable $-y i$. This realization corresponds to lim- $a+$ lim-el- $a$ in (18a). The third stem-level reduplication consists of the root dl- plus the vowel [e] of applicative -el-followed again by the dummy $-y i$. This realization corresponds to lim-e + lim-el-a in (18a). Turning to (31b), here we see two alternatives where reduplication has gone up to the macro-stem level. In both cases the object prefix $z i$ - is copied: In the first realization, applicative - $e l$ - is truncated and the default FV -a appears. In the second realization, the [e] of applicative - $e l$ - is parsed. The Ndebele facts show how extra-stem material, namely the object prefix, can be copied in RED in case the root material has been exhausted. Crucially, there is no requirement to exhaust stem-level material before moving up to the macro-stem. We therefore need to extend the three-way distinction made in (20) as follows: (i) root material must copy; (ii) an extension on object prefix may copy; (iii) inflectional endings may not copy.

In Ndebele, the only pre-stem material which can be copied in RED is the object prefix, and only if there is a second syllable slot available for it. In Kihehe any prefix may appear in RED which syllabifies with the root (Odden and Odden 1985; Odden 2001). As seen in (32a), RED generally excludes prefixes:

$$
\begin{aligned}
& \text { a. object prefix : kú-fi-gúl-a } \rightarrow \quad \text { (kú-fi-) gul-a + gúl-a } \\
& \text { 'to buy a bit of them' } \\
& \text { b. infinitive ku- : kú-tov-a } \rightarrow \text { (kú-) tov-a + tóv-a } \\
& \text { c. subject prefix : tu-gul-iite } \rightarrow \text { (tu-) gul-iite }+ \text { gúl-iit-e } \\
& \text { 'to beat a bit' } \\
& \text { 'we shopped a bit' }
\end{aligned}
$$

Although Kihehe has full-stem reduplication, the above forms would be ungrammatical with prefix copying, e.g. *(kú-) fi-gul-a +fi-gúl-a. In (33), on the other hand, we see that prefixes which syllabify with the base are copied:

$$
\begin{aligned}
& \text { a. object : kú-mw-iimb-il-a } \rightarrow \text { (kú-) mw-iimbil-a + mw-iimb-íl-a } \\
& \text { b. infinitive : kw-íimb-a } \rightarrow \text { kw-íimb-a + kw-iímba } \\
& \text { 'to sing a bit to him' } \\
& \text { c. subj+obj : n-gw-iítite } \\
& \text { 'to sing a bit' } \\
& \rightarrow \text { n-gw-itite }+ \text { n-gw-iítite }
\end{aligned}
$$


These examples all involve a vowel-initial root before which the class 1 object prefix /mu-/ is realized $m w$ - in (33a) and the infinitive prefix /ku- $\rightarrow k w$ - in (33b). As a result of this fusion, pre-stem material is copied in RED. This is most striking in (33c), where both the first person subject prefix $n$ - and the class 3 object prefix $/ \mathrm{gu}-/(\rightarrow g w-)$ are copied, presumably reflecting that the initial syllable is [ $\left.\widehat{\sim}{ }^{\mathrm{W}_{\mathrm{ii}}}\right]$. The fact that both the infinitive prefix and subject prefixes can be copied shows that the macro-stem is irrelevant in Kihehe. The same point can be made from Swati, where Ziervogel (1952, p. 81) reports the copying of a subject prefix which fuses with a -VC- root, e.g. /ba-ev-a/ 'they hear' $\rightarrow 6-e v-a \rightarrow 6-e v-a+6-$ $e v-a$.

The cases just examined demonstrate two different phonological motivations for including prefixes in RED: A prefix may either provide the second syllable in the case of subminimal root, or it may be copied by virtue of being syllabified with the root. The significance of Ndebele and Kihehe is that they provide innovative models by which verb-stem reduplication could become macro-stem- or even full-word reduplication by analogy. In other words, there is a way to enlarge the domain of reduplication.

\subsection{Incorporation of Inflectional suffixes}

In Sect. 4 we saw that there is a tendency for full-stem reduplication to undergo morphological and phonological reduction. Most of the cases where verb-stem reduplication is less than total fall into two classes: (i) RED is identical to a PHONOLOGICAL constituent at the left edge of the base, e.g. the first syllable or bisyllabic foot. (ii) RED is identical to a MORPHOLOGICAL constituent at the left edge of the base, e.g. the root, with possible fillers (default $-a$, dummy - $y i$ etc.). There are, however, cases where here neither of these conditions is met, with morphophonemic processes causing the RED and base to become phonetically dissimilar. When this happens, a counter-tendency to build towards full-stem reduplication sometimes shows up.

As a first illustration, let us return to Ndebele, which, it will be recalled, disallows inflectional material to be copied into RED. Of concern here are the complications concerning the realization of the perfective (Hyman et al. 2009). As seen in (34a), when the base is a -CVC- root, the perfective is formed by simple suffixation of $-i l-e$ :
a. bá-gan-il-e bá-dal-ile
'they became betrothed'
b. bá-hamb-el-an-il-
'they created'
c. bá-thath-il-e
bá-sál-il-e

$\rightarrow$ bá-béth-ain-
$\rightarrow$ bá-thaith-e
$\rightarrow$ bá-sail-e
bá-hamb-el-en-e 'they agreed'
$\rightarrow$ bá-béth-en-e 'they clashed'
$\rightarrow$ bá-theth-e 'they took'
$\rightarrow$ bá-sel-e 'they remained'


However, when the base is longer, many Bantu languages show fusion or "imbrication" of perfective -il-e. In the examples in (34b), the [i] of -il-e is imbricated before the last consonant (here the $/ \mathrm{n} /$ of the reciprocal extension -an-), and the [1] is deleted. The resulting [ai] sequence is attested in other Bantu languages, but monophthongizes to [e] in Ndebele. The derivations in (34c) show that some -CVC- roots which were historically bimoraic exceptionally undergo imbrication as well. Since this [e] fuses inflectional [i] with non-inflectional [a], the question is how it is viewed in the reduplication process.

As seen in (35a), if the fused [e] appears in the third (or later) syllable of the imbricated stem, there will be no complications:
a. bá-hamb-el-en-e $\rightarrow$ (bá-)hamb-e + hamb-el-en-e 'they agreed a bit /bá-hamb-el-an-il-e/ hamb-a + hamb-el-en-e here and there'
b. bá-béth-en-e /bá-béth-an-il-e/
c. bá-théth-e /bá-tháth-il-e/ $\rightarrow$ (bá-)béth-a + beth-en-e 'they clashed a bit $\sim$ béth-e + beth-en-e here and there
$\rightarrow$ (bá-)tháth-a + theth-e $\sim$ théth-a + theth-e 'they took a bit here *(bá-)théth-e + theth-e
d. *bá-tháth-il-e (bá-)tháth-a + thath-il-e

As we saw in (18), there are two variants: the first copies the [e] of applicative -el-, while the second truncates $-e l$ - and uses the default FV $-a$. The two variants are therefore as expected. Now consider the two variants in (35b). While the first RED has truncated all suffixal material to produce beth-a, the second RED, beth-e, has copied the first two syllables of the base. Recall that this $-e$ results from the fusion of the [a] of the reciprocal extension -an-with the [i] of perfective -il-e. In other words, the front feature of [i] has been copied even though Ndebele normally prohibits inflectional material from RED. The same options are seen in $(35 \mathrm{c})$, where the front feature can be realized on the root syllable of RED.

The interpretation which Hyman et al. (2009) give to doublets such as in (35b,c) is that Ndebele speakers vary in whether they treat the fused [e] as inflectional or non-inflectional: While the front feature derives from underlying /-il-/, the vowel slot on which it is realized belongs either to a derivational suffix or to the root. The third starred form in (35c) shows that it is not possible for the FV - $e$ to appear in RED since it is unambiguously inflectional. Note in (35d) that although /tháth-il-e/ obligatorily undergoes imbrication in the simplex form, imbrication can be optionally blocked in the corresponding reduplication (Sibanda 2004). In this case inflectional -il-e is not copied, and thath-is realized identically in RED and in the base.

The significance of these facts is twofold. First, forms such as beth-a + beth-en-e and especially thath- $a+$ theth-e again provide a way in which a smaller domain (the verb base or derivational stem) may reach out to include material from a larger one (the inflectional stem), which is otherwise prohibited. This is also seen in closely related Swati, which, like Ndebele, normally disallows -il-e in RED, but may copy -il-when it follows a -VC- root (Ziervogel 1952, p. 81): 

a. en-
'be overgrown'
+ PER
b. om-
'become dry'
+ PERF
en-il-e $\rightarrow$
en-il-a + n-il-e

The expected Ziervogel mentions the latter as a variant. (-VC- roots often alternate with -yV- in Bantu.) In (36) the initial root vowel is excluded from the process, leaving $n$-il-e and $m$-il-e as the inputs to reduplication. Since $-n$ - and $-m$ - are subminimal, $-i l-$ is incorporated into the base as if it were a derivational extension rather than part of the inflection ending -il-e. However, inflectional - $e$ may not be copied into RED (*enil-e $+n$-ile, *om-il-e $+m$-il-e).

The second significance of imbrication is that outputs like thath- $a+$ theth-e and sal-a + sel-e (from /sal-il-e/ $\rightarrow$ sel-e in (34c)) now produce forms in which the reduplicants and bases start to drift apart from each other. Such forms are the only ones where the first vowel of RED is different from the root vowel. To make the two parts more similar, the alternative forms theth- $a+$ theth-e and sel- $a+$ sel-e become acceptable. The logical endpoint of such a strategy would be to make the reduplicant and the base exactly identical, i.e. to have total copy. While *theth$e+$ theth-e and *sel-e + sel-e are not acceptable in Ndebele, other Bantu languages seem to have taken the step of re-introducing inflectional endings into RED.

One such case concerns Luvale (Lwena) about which Horton (1949, p. 101) writes: "The Frequentative form indicates that the action or state is repeated a number of times or applies to a number ofsubjects.... This derivative is formed by reduplication of the stem. Originally these reduplicated stems were treated as single verbs, with single inflectional suffixes. Today, in the case of disyllabic stems in the perfect, both parts of the reduplicated form undergo mutation...." What this means is that the earlier structure in (37a) involving root reduplication is being replaced by full stem reduplication in $(37 \mathrm{~b})$.

$$
\text { a. [ [ROOT-a-ROOT ] INFL ] b. [ [ ROOT - INFL ] [ ROOT - INFL ] ] }
$$

In the perfect, Luvale uses a pattern common in central-western Bantu (Grégoire 1979), whereby the FV is - $e$ after -CaC- roots, as in (38a), otherwise a copy of the root vowel, as in (38b).
a. tu-na-tal-e tu-na-mbat-e
b. tu-na-het-e tu-na-mon-o tu-na-hik-i tu-na-tumb-u
c. tu-na-lis-a tu-na-ci-many-is-a tu-na-hambakan-a

\author{
'we have looked for' \\ 'we have carried' \\ 'we have arrived' \\ 'we have seen' \\ 'we have stirred' \\ 'we have planted' \\ 'we have caused to eat' (/li-is-/ 'eat-CAus') \\ 'we have finished it' \\ (/man-is-/ 'finish-CAUs')
}


As seen in (38c), derived and longer verb stems take the FV $-a$. Horton indicates that reduplications were originally treated as one long base, thus taking $-a$ in the perfect, as in (39a).
a. (va-na-ci-) tal-a + tal-a
[ [ tal-a-tal ] -a]
'they have looked for it'
b. (va-na-ci-) tal-e + tal-e
$[$ [ tal-e] [ tal-e] ]

However, he adds that speakers "now frequently" use innovative forms such as in (39b), where the FV - $e$ appears also in RED. That the motivation is to derive total identity between the two parts of the reduplicated verb stem is confirmed in the remote past tense in (40).
a. (va-mu-) vet-a + vet-el-e 'they each of them struck him
b. (va-mu-) vet-el-e + vet-el-e again and again'
[ [ vet-a-vet ] -el-e ]
[ [ vet-el-e] [ vet-el-e] ]

As indicated, the older variant in (40a) shows a reduplicated ROOT- $a$-ROOT followed by a single inflection. However, Horton points out that speakers "now often" produce forms such as in (40b), where the perfective ending -el-e occurs in RED. This points to the first of two conceptual conflicts, that between the two desirable analyses in (41), where BASE is used in the Bantu sense of ROOT + possible derivational extensions:
a. $\left[[\text { BASE }]_{i}+[\text { BASE }]_{i}\right]+$ INFL $]$
reduplicated base + single inflection
b. $[\text { BASE }+ \text { INFL }]_{i}[\text { BASE }+ \text { INFL }]_{i}$
reduplicated compound stem with inflection

As shown in (41a), speakers would like to reduplicate the base with a single inflection. This can result in a truncated RED, as in vet-a +vet-el-e. On the other hand, they would like a reduplicated compound stem where the two parts are identical, as in vet-el-e + vet-el-e. Since both structures are motivated, the diachronic implication is that either should be able to change into the other.

A second conceptual conflict concerns the question of whether the reduplicated verb stem consists of one BASE or two? In Mambwe, the perfective is realized -il-e after CVC- roots (whose final consonant may undergo mutation), as in (42a), but is imbricated after longer roots, as in (42b) (Halemba 1994):

\begin{tabular}{|c|c|c|c|c|}
\hline \multirow{8}{*}{$\begin{array}{l}\text { land- } \\
\text { sent- } \\
\text { lil- } \\
\text { lot- } \\
\text { fum- } \\
\text { pongan- } \\
\text { pelem- } \\
\text { vwitik- }\end{array}$} & + il-e & $\rightarrow$ & lanz-il-e & 'talk' \\
\hline & il-e & $\rightarrow$ & sens-il-e & 'gnaw' \\
\hline & il-e & $\rightarrow$ & liz-il-e & 'cry' \\
\hline & + il-e & $\rightarrow$ & los-il-e & 'dream' \\
\hline & il-e & $\rightarrow$ & fum-il-e & 'go out' \\
\hline & + il-e & $\rightarrow$ & pongin-e & 'be unrecognizable' \\
\hline & + il-e & $\rightarrow$ & pelim-e & 'disobey' \\
\hline & il- & $\rightarrow$ & vwitik-e & 'bewitch' \\
\hline
\end{tabular}




$$
\begin{aligned}
& \text { folol- }+ \text { il-e } \rightarrow \text { folwil-e 'scratch' } \\
& \text { simul- }+ \text { il-e } \rightarrow \text { simwil-e 'run' }
\end{aligned}
$$

Of relevance here is how the perfective is realized on reduplicated verb stems, i.e. whether the latter are treated as one long base or two short ones. Both possibilities are attested. Most lexicalized reduplications which have no transparent simplex base are treated as a single base and hence undergo a single imbrication as in (43).
a. [ fuk-a-fuk ] + il-e $\rightarrow$ fuk-a-fwik-e 'be restless, fidgety'
b. [ tang-a-tang ] + il-e $\rightarrow$ tang-a-ting-e 'be embarrassed, perplexed'
c. [ tuw-a-tuw ] + il-e $\rightarrow$ tuw-a-twiw-e 'be slow, lazy'

On the other hand, most productive or semantically transparent reduplications are treated as two bases, only the second of which is visible to the perfective morphology. Where the second base is short, there is no imbrication, as seen in (44).
a. [ lap-a ] [ lap ] + il-e $\rightarrow$ lap-a + laf-il-e
'swear often without good reason'
(cf. lap-a 'swear')
b. [ cit-a $][$ cit $]+$ il-e $\rightarrow$ cit-a + cis-il-e
'do as one wishes, not following rules' (cf. cit-a 'do bad things') (cf. kow-a 'catch, grab, cling to')
c. [ kow-a] [ kow ] + il-e $\rightarrow$ kow-a + kov-il-e 'fumble everything'

Even though the final consonant often undergoes mutation to [f] or [s] before -il-e, the motivation for not imbricating is that there is greater identity between RED and the base, which will have an identical initial CV (and sometimes CVC). Still, while I expect that (44) represents the way that productively created reduplications would be realized in the perfective, as well as most of those which are lexicalized but transparent, there are a few of the latter which exceptionally undergo imbrication, as in (45).
a. [ cew-a ] [ cew ] + il-e $\rightarrow$ cew-a + ciw-
'look all around'
(cf. cew-an-a 'look, wink at e.o.')
b. [ suk-a ] [ suk ] + il-e $\rightarrow$ suk-a + swik-e 'be restless, fidgety' (cf. suk-an-a 'fidget, wriggle body')


In fact, there is the following minimal pair in (46).

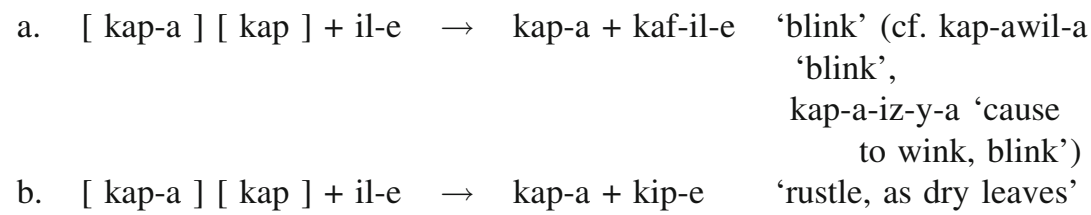

As seen, (46a) does not undergo imbrication, as there are related verbs with the root kap-. (46b), on the other hand, does not have any obviously related verb (other than the derivative kap- $a+k a p-o l-a$ 'cause to rustle') and hence undergoes imbrication.

We have not addressed the question of which perfective strategy is older. Before we do, consider how longer reduplicated verb stems form the perfective in (47).
a. simul-a + simul-a $\rightarrow$ simwil-e + simwil-e 'run here and there'
b. pongan-a + pongan-a $\rightarrow$ pongin-e + pongin-e 'be completely
c. folol-a + folol-a $\rightarrow$ folwil-e + folwil-e 'scratch all over'

As seen, both stems are imbricated (cf. the corresponding unreduplicated verb stems in (42b)). The reason is clear: If the outputs had been *simul-a + simwil-e, *pongan- $a+$ pongin-e, and *folol- $a+$ folwil-e, there would have been a significant difference between the two parts of the reduplication. As in the case of lap-a + lafil-e 'swear often without good reason' versus *lap- $a+$ lif-e in (44), the preferred form is the one where the vowels of RED and the base are identical. Two strategies are employed to achieve this effect: Imbrication underapplies in (44), where the roots are CVC-, but overapplies in (47), where the inputs are CVCVC-. That -il-e is not expected to be copied, is seen not only from the CVC-a-CVC-il-e bases in (44), but also from longer verb bases such as in (48).
a. sinteek- + il-e $\rightarrow$ sintees-il-e
'cauterize over a large area'
b. sukook- + il-e $\rightarrow$ sukoos-il-e
'wriggle continuously one's body'
c. peelook- + il-e $\rightarrow$ peeloos-il-e 'give much without measure'

What these have in common is the length of their penultimate vowel, which blocks imbrication. As seen now in (49), -il-e is not copied in the corresponding reduplications:
a. sinteek-a + sintees-il-e 'cauterize all over'
b. sukook-a + sukoos-il-e 'wriggle continuously one's body'

Finally, reduplicated subminimal roots are not consistent with respect to -il-e: 

a. $\quad$ sy-a
$\rightarrow$ s-il-e
'leave'
sy-a + sy-a
$\rightarrow \quad$ s-il-e + s-il-e
'leave things lying
about'
sy-a + sy-a + sy-a $\rightarrow$ s-il-e + s-il-e + s-il-e
'leave things lying all over the place'
b. fw-a
$\rightarrow$ fw-il-e 'die'
fw-a + fw-a
$\rightarrow$ fw-a + fw-il-e
c. pw-a
$\rightarrow$ pw-il-e
pw-a + pw-a
$\rightarrow$ pw-il-e
'die in big numbers'
'dry up'
'get dry frequently'

As seen, -il-e is copied in (50a), but not in (50b). Curiously, Halemba (1994, p. 692) provides the same -il-e form for $p w-a+p w-a$ as he does for $p w-a$. Since -il-e is regularly copied into RED only when imbricated, it would seem logical to consider this an innovation, as in Ndebele. Again, we see that the domain of reduplication can be extended "upwards"' to incorporate the inflectional ending.

Not mentioned thus far is the possibility of a semantic conflict between the perfectivity of -il-e and the frequentative meaning. At the very least, reduplicated perfectives may occur less commonly than non-perfectives. An indication of this comes from Bemba: "Generally the use of the -ILE tenses is avoided, but when they are used the tenses are repeated...'" (van Sambeek 1955, p. 91) While Bemba requires full verb stem reduplication, two different tone patterns are reported by Sharman (1963, p. 82-83):

a. (bá-a-) [ lim-íné + lím-íné ] 'they hoed by fits and starts'

b. (bá-a-) [ lim-íné ] + [ lim-íné ] 'they hoed enormously (or scrappily, badly)'

$\mathrm{H} \quad \mathrm{H}$

In (51a) a single $H$ tone suffix is linked from the second to the last vowel of the reduplicated stem. In (51b), however, there are two suffixal $\mathrm{H}$ tones which are linked to the second and final vowel of each part of the reduplicated stem. In (51a), as in most Bantu languages, speakers treat the reduplicated verb as a single stem which receives one intonational pattern just like other stems. In (51b), two inflectional tone patterns are assigned to the reduplicated verb. This is extremely rare in Bantu, the only well-known case being Chichewa (Carleton and Myers 1996, Hyman and Mtenje 1999). ${ }^{6}$ Examples involving the hortative are observed in (52).
a. ti-tandiz-é $\rightarrow$ ti-tandiz-é tandiz-é
'let's help here \& there'
b. ti-vundikir-é $\rightarrow$ ti-vundikir-é vundikir-é 'let's cover here \& there'
c. ti-khululukir-é $\rightarrow$ ti-khululukir-é khululukir-é
'let's pardon here \& there'

As seen, a single $\mathrm{H}$ tone appears on the FV of each stem. Hyman and Mtenje (1999) present arguments that the second stem constitutes a separate phonological word,

\footnotetext{
${ }^{6}$ Subiya may also copy tone in verb-stem reduplication (Joyce Mathangwane, pers. comm.)
} 
which again makes Chichewa verb reduplication quite different from other Bantu languages. Since Chichewa is not a particularly conservative Bantu language (e.g. it has lost -il-e and the nominal "augment" and has innovated contrastive tones on verb extensions), it is likely that it is innovative in its verb-stem reduplication as well. In other words, Chichewa is an extreme case of rebuilding full reduplication from an earlier system. We next turn to consider why this may have happened.

\section{A new hypothesis: bidirectionality}

In the preceding sections I have documented some of the variation on the realization of RED in verb reduplication in different Bantu languages: Some impose a bisyllabic condition, some ban inflectional material, some allow prefixes to creep in, some under- or overapply imbrication of perfective -il-e, and so forth. At the one end is full-stem reduplication, at the other, a bisyllabic (more rarely monosyllabic) maximum. It is not hard to explain why such variation exists, since both fulland partial-reduplication are motivated by conflicting principles. Consider, first, full-stem reduplication. In this case the two parts of the reduplicated verb are exactly identical, as expected of reduplication, especially at its early "iconic" stage. This identity thus avoids the phonological or morphological mismatch problems which arise in partial reduplication. Finally, full-stem reduplication is more in keeping with the reduplication processes affecting other parts of speech in Bantu: reduplicated noun- and adjective stems are rarely truncated, and numerals typically show full-word reduplication, as was seen in Kanyok in (11) above.

On the other hand, full-stem reduplication has disadvantages. The first is the "effort" problem: the stem can be quite long, hence awkward to repeat in toto. Recall from (14) that Ciyao has full-stem reduplication. It also allows quite complex verb stems, as the octosyllabic example in (54) shows (Ngunga 2000):

taam-uk-ul-igw-aasy-an-il-a 'cause each other to be unseated for/at' be seated-IMPOSITIVE-REVERSIVE-PASS-CAUS-RECIP-APPL-FV

If reduplicated, the result would be 16 syllables, which is considerable overkill when one considers that from a semiotic point of view, RED realized only one sememe, e.g. \{frequentative\}. In terms of marking the frequentative construction, repeating all of the extensions and an inflectional FV does no more than, say, copying the first CV-. There is also the semantic issue that verb-stem reduplication typically is concerned with a diminution or intensification of the lexical root meaning ('do something a little bit here \& there, perhaps aimlessly or badly'), which ultimately can become disassociated from the original meaning, as we have seen in some of the glosses. From a semantic point of view derivational suffixes are schizophrenic. To the extent that they are frozen or contribute unpredictably to the lexical meaning, it would make sense to copy them as well. Where they have a productive, grammatical function, e.g. licensing a causative or applicative argument, as in the Ciyao example in (53), it would seem less motivated for them to 
appear in RED. In cases where the semantics of the extension is specifically targeted, the extension may itself be repeated, as when causative -is- is used with an intensive function in Shona (Dembetembe 1978, p. 43):

$\begin{array}{llll}\text { fár-a } & \begin{array}{l}\text { 'be happy' } \\ \text { nak-a }\end{array} & \text { 'be good' } & \text { 'hold' } \\ \text { fár-ís-á } & \begin{array}{l}\text { 'be too happy } \\ \text { nak-is-a }\end{array} \text { 'be very good' } & \text { bát-ís-á } & \text { 'hold fast' } \\ \text { fár-ís-ís-a } & \begin{array}{l}\text { 'be excessively happy' } \\ \text { 'be extremely good' }\end{array} & \begin{array}{l}\text { bát-ís-ís-a } \\ \text { firmly' }\end{array} & \text { 'hold very }\end{array}$

Since reduplication originally targets the lexical meaning of the root, it makes less sense for the tense/aspect/mood endings to be repeated in RED. Interestingly, it is in those languages which have most reduced RED (e.g. to a single syllable) that imperfective or habitual aspectual meanings are observed. There is, however, no reason to think that copying of the inflectional endings $-i$, $-e$, or -il-e contributes to the semantic drift towards "more general meanings" (Bybee et al. 1994).

What this means is that RED is subject to a conflict between IDENTITY versus. ECONOMY, i.e. between the expressive demands of full-stem identity vs. the various phonetic shortcuts that have been observed. In this context it should be noted that most nouns have bisyllabic stems in Bantu, which also produce a two-syllable RED, as was seen in (12a).

Given that both full and reduced reduplication are motivated by conflicting concerns, I would like at this point to advance the hypothesis in (55).

$$
\begin{aligned}
& \text { Hypothesis: the historical development of RED goes in both directions } \\
& \begin{array}{llll}
\text { a. full }>\text { partial } & \text { b. partial }>\text { full }
\end{array}
\end{aligned}
$$

(55a) recapitulates the general assumption that partial reduplication derives historically from full reduplication (Eulenberg 1971; Bybee et al. 1994; Niepokuj 1997; but cf. Hurch and Mattes 2005). In previous sections we have observed both full verb-stem reduplication as well as various reduced versions of RED predicted by the phonological and morphological scales in (21). However, we have also seen cases where prefixes and inflectional endings become incorporated in RED in order to fulfill minimality or to enhance the identity between RED and the corresponding full stem. As mentioned earlier, either of these considerations could in principle provide the model for extending the direction in $(55 \mathrm{~b})$.

In fact, there is reason to speculate that the original reduplication applied only to the verb root. ${ }^{7}$ The main argument is that verb reduplication is so widespread in

\footnotetext{
7 Tak (2003) argues for an original bisyllabic RED in PB on the basis of its economy of effort, its frequency in the world's languages, and the naturalness of replacing it with full reduplication (which is said to constitute an improvement in learnability). While my emphasis has been on establishing the morphological constituents that could be copied, Tak is mostly concerned with the bisyllabic constraint (which does not necessarily rule out derivational or inflectional material in RED). As will be seen, we both recognize that there are motivations for change in either direction: A shorter, e.g. bisyllabic, RED is superior to a longer RED, but an exact copy is more transparent than a truncated RED.
} 
Niger-Congo that it had to predate the evolution of at least some of the verb morphology. In Sect. 2 I alluded to the controversy surrounding the question of whether pre-stem morphemes were prefixes, clitics, or separate words in PB. In addition, there are arguments that at least some of the inflectional endings have a shallow history. In Hyman (1993, pp. 21-23) I present evidence which suggests that "perfective $*_{-} i d$-, just like imperfective $*_{-}$ag-, went through a clitic stage, and in fact is only now being fully incorporated as a regular suffix within the Bantu verb stem." 8 A second argument is that there are lexicalized reduplicated verbs which copy only the first syllable. As seen in the following examples from Kinyarwanda (Kimenyi 2002, pp. 254-255, 260), some of these have meanings suspiciously similar to the verb-stem reduplication semantics surveyed in (8), specifically, 'do a little bit here \& there, perhaps aimlessly (56a) or badly (56b)':
a. bé-beer-a
jáa-jaab-a
hwíi-hwis-a
'go around aimlessly'
( béer-a + beer-a)
b. búu-buut-a 'gossip'
dé-demaang-a
'walk bent (old age)'
( búut-a + buut-a)
sé-serez-a
'stutter'
'miscut nails'

As mentioned, the semantics concerns the action of the verb, not the extensions or inflection. If these reduplications pre-date the requirement that all verbs end in a FV (Grégoire 1979), the earlier forms might well have had abutting consonants. The two forms of 'walk bent' might then have come from *búut-búut and *búut-a+ búut- $a$, respectively.

The suggestion, then, is that the PB derived verb in (57a) first reduplicated as in (57b).
a. $\quad$ PB $*$ dim-Id-an-a cultivate-APPL-RECIP-FV
b. $\quad$ PB *dim-a + dim-Id-an-a

'cultivate for each other'

If correct, this means that Kikerewe lim-il-an-a + lim-il-an- $a$ from (15) would have to be an innovation, and that lim-il-a + lim-il-an-a might have two sources: partial build-up from lim- $a+$ lim-il-an- $a$ or partial build-down from lim-il-an-a + lim-il$a n-a$. In $\$ 7$ we conclude by considering why verb-stem reduplication is robustly prefixal in Bantu.

\footnotetext{
8 As expected, floating $\mathrm{H}$ tone prefixes are not reduplicated, e.g. the $\mathrm{H}$ assigned by the infinitive prefix $\mathrm{ku}$ - in Chichewa. What would be particularly persuasive would be a language which reduplicates a root $\mathrm{H}$ tone, but not an inflectional $\mathrm{H}$ tone suffix. I am unaware of any such cases.
} 


\section{Conclusion}

In the preceding sections I have documented the considerable variation found in verb-stem reduplication in Bantu. While it seems overwhelming likely that PB had verb-stem reduplication, determining the shape of the PB reduplicant is less clear. Both full-stem reduplication and root-only reduplication were said to have advantages. Copying the full stem (root+suffixes) has the advantage of guaranteeing identity of the two parts. On the other hand, full-stem reduplication can become quite unwieldy. We thus have seen that RED can be subject to restrictions that are either morphological (e.g. don't copy inflectional endings) or phonological (e.g. maximum of two syllables). Phonological innovations may, however, also motivate the incorporation of inflectional prefixes and endings, thereby building up RED on both peripheries. In all cases we note the primacy of the root in reduplication: As was schematized for Ndebele in (20), non-root material can appear in RED only if all of the root material has been exhausted. This presumably has to do with the function of the construction, which is to comment on the quantity, quality, or extent involved in carrying out the lexical root semantics.

The supremacy of the root may also explain why verb-stem reduplication is prefixal. Whenever truncated, RED is clearly preposed to the full stem. Hyman et al. (2009) and Downing (2004) report a speaker of Bukusu, who omitted productive extensions in preposed RED, as in (58a), but variably truncated the root-initial syllable of postposed RED, as in (58b).

$$
\begin{aligned}
& \text { a. lim-il-a 'cultivate for/at' } \rightarrow \text { lim-a + lim-il-a } \\
& \text { rém-er-a 'cut for/at' } \rightarrow \text { rém-a + rem-er-a } \\
& \text { b. kacul-a 'chat, talk' } \rightarrow \text { kacul-a + cul-a } \\
& \text { mulix-a 'flash' } \rightarrow \text { mulix-a + lix-a }
\end{aligned}
$$

Of the 334 quadrisyllabic or longer verb stems in Khisa et al. (2000), I found 46 lexicalized reduplications of which the following three contain bases of three syllables:
a. sób-a + soban-a
'be of uneven length or size'
b. kali + kalikan-a
'complicate oneself, do stubbornly'
(cf. kalikan-a 'complicate')
c. mulix-a + mulix-a
'twinkle' (cf. mulix-a 'flash (of lightning), to flower')

While the first two show a preposed RED, the third exhibits total reduplication (conflicting with the output in (58b)). No lexicalized verbs were found of the shape of kacul- $a+c u l-a$, suggesting that this may be an innovation.

Except for this Bukusu case, suffixal verb-stem reduplication appears to be avoided in Bantu. The reason for this is not hard to understand. The non-occurring forms in (60) are intended to be reminiscent of the bisyllabic RED in Ndebele, but which is instead postposed: 
(60)

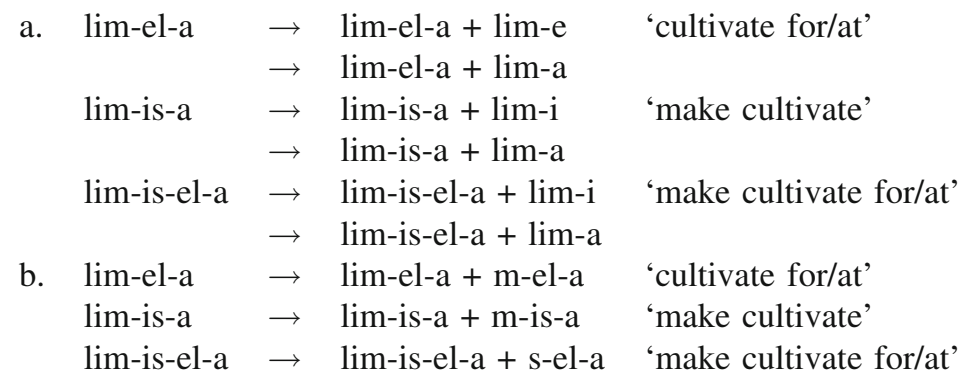

In (60a) the stem material is mapped left-to-right onto the postposed bisyllabic RED. As seen, the result is an "entrapment" of productive derivational suffixes (applicative - $e l$ - and causative - $i s$-) inside the verb. A worse outcome is seen in (60b), where the segmental material of the base stem is mapped right to left. As seen, there is not only internal entrapment of -el- and -is-, but also failure of root material to be copied into RED. The first two examples have only the final $/ \mathrm{m} /$ of /lim-/ 'cultivate', while the third example has no root material in RED. While Nelson (2002) suggests that there is a prefixing preference for RED in general, Hyman et al. (2009) argue that the unmarked positon for RED is "opposite edge affixation", as in (61).

(61) a. The reduplicant will tend to be preposed when the base has a suffixing structure

b. The reduplicant will tend to be postposed when the base has a prefixing structure

Since the verb stem has a suffixing structure, RED is preposed. Since nouns have a prefixal structure, RED is postposed in word-level nominal reduplication (recall the Kinande examples seen in (12a)). By developing a truncated RED on the opposite side of affixation, the result is that affixes do not get entrapped as in (60).

The final question concerns the role of inflection in verb-stem reduplication. We have seen several examples where there has been an option or a requirement that the inflectional endings other than $-a$ be excluded from RED, in some cases even when derivational suffixes can be copied. The same issue actually arises in cases of looser reduplication or word repetition, in fact in English. The following number of hits on Google were obtained on September 4, 2007:

\footnotetext{
a. "was/were talking talking talking": 596 hits

“'I wasn't mad, I was confused... everyone was talking, talking, talking at me and I couldn't understand a word they were saying...',

b. "was/were talk talk talking"': 169 hits

"she was talk-talk-talking away on her cell phone, holding it to her ear with one hand and gesticulating wildly with the other..."
}

Although the numbers differ, with the verb talk it is possible to repeat the inflected participle talking, as in (62a), or express it once only on the last of the three verbs, 
as in (62b). I also queried Google with respect to the third person singular $-s$, where the numerical differences turned out to be much more dramatic:

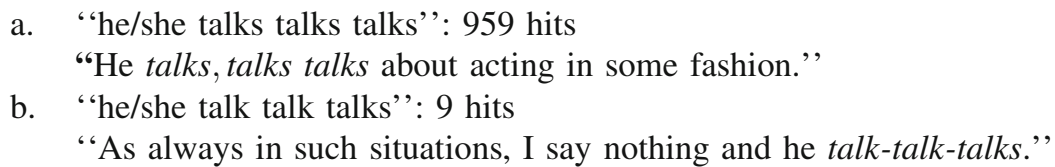

While we are a long way from Ndebele verb-stem reduplication, the same question arises: Which is older? If the direction of change is from word repetition to reduplication, as it appears to be in English, then the inflected form is older. I have, however, tried to argue that both directions make sense in Bantu, where one can also claim that root reduplication expanded to include derivational and inflectional material. Additional research will hopefully provide definitive evidence concerning the origin and development of verb-stem reduplication in Bantu.

Open Access This article is distributed under the terms of the Creative Commons Attribution Noncommercial License which permits any noncommercial use, distribution, and reproduction in any medium, provided the original author(s) and source are credited.

\section{References}

Aroga Bessong, D. P., \& Mel'cuk, I. A. (1983). Un modèle formel de la conjugaison bafi (à l'indicatif). Bulletin of the School of Orieintal and African Studies, 46, 477-528.

Ashton, E. O. (1944). Swahili grammar (including intonation). London: Longman, Green \& Co.

Bastin, Y., \& Schadeberg T. (Eds). (2003). Bantu Lexical Reconstructions 3. Tervuren: Royal Museum for Central Africa. Online Database, http://www.metafro.be/blr

Bybee, J., Perkins, R., \& Pagliuca W. (1994). The evolution of grammar: Tense, aspect and modality in the languages of the world. Chicago: University of Chicago Press.

Carleton, T., \& Myers S. (1996). Tonal transfer in Chichewa. Phonology, 13, 39-72.

Cole, D. (1955). An introduction to Tswana grammar. London: Longman, Green \& Co.

Dembetembe, N. C. (1978). Reduplication in Shona and its semantic effect. In E. J. M. Baumbach (Ed.), Second African languages congress of UNISA (pp. 20-58). Pretoria: University of South Africa.

Downing, L. J. (1999). Morphological constraints on Bantu reduplication. Linguistic Analysis, 29, 6-46. Downing, L. J. (2001). Ungeneralizable minimality in Ndebele. Studies in African Linguistics, 30, 33-58.

Downing, L. J. (2003). Compounding and tonal non-transfer in Bantu languages. Phonology, 20, 1-42.

Downing, L. J. (2004). Bukusu reduplication. In C. Githiora, H. Littlefield, \& V. Manfredi (Eds.), Trends in African linguistics 5 (pp. 73-84). Lawrenceville, NJ: Africa World Press.

Eulenberg, J. B. (1971). Conjunction reduction and reduplication in African languages. In C.-W. Kim \& H. Stahlke (Eds.), Papers in African linguistics (pp. 71-80). Edmonton: Linguistic Research, Inc.

Fisch, M. (1998). Thimbukushu grammar. Windoek, Namibia: Out of Africa Publishers.

Fortune, G. (1982). Shona grammatical constructions, Part II. Harare: Mercury Press.

Grégoire, C. (1979). Les voyelles finales alternantes dans la conjugaison affirmative des langues bantoues centrals. Journal of African Languages \& Linguistics, 1, 141-172.

Guthrie, M. (1939/1966). Grammaire et dictionnaire de lingala. Westmead: Gregg Press Ltd.

Halemba, Fr. A. (1994). Mambwe-English dictionary. Ndola, Zambia: Mission Press.

Horton, A. E. (1949). A grammar of Luvale. Johannisberg: Witwatersrand University Press.

Hurch, B., \& Mattes V. (2005). Über die Entstehung von partieller Reduplikation. In G. Fenk-Oczlon \& C. Winkler (Eds.), Sprache und Natürlichkeit. Gedenkband für Willi Mayerthaler (pp. 137-156). Tübingen: Narr.

Hyman, L. M. (1993). Conceptual issues in the comparative study of the Bantu verb stem. In S. S. Mufwene \& L. Moshi (Eds.), Topics in African Linguistics (pp. 3-34). Amsterdam: Benjamins. 
Hyman, L. M. (2007). Reconstructing the Proto-Bantu verbal unit: internal evidence. In N. C. Kula \& L. Marten (Eds.), Bantu in Bloomsbury: Special issue on Bantu linguistics. SOAS Working Papers in Linguistics 15 (pp. 201-211). London: University of London.

Hyman, L. M., Inkelas, S., \& Sibanda, G. (2009). Morphosyntactic correspondence in Bantu reduplication. In K. Hanson \& S. Inkelas (Eds.), The nature of the word: Essays in Honor of Paul Kiparsky (pp. 273-310). Cambridge, MA: MIT Press.

Hyman, L. M., \& Katamba, F. X. (2005). The word in Luganda. In F. K. E. Voeltz (Ed.), Studies in African linguistic typology (pp. 171-193). Amsterdam: John Benjamins.

Hyman, L. M., \& Mtenje A. (1999). Prosodic morphology and tone: The case of Chichewa. In H. van der Hulst, R. Kager, \& W. Zonneveld (Eds.), The prosody-morphology interface (pp. 90-133). Cambridge: Cambridge University Press.

Inkelas, S., \& Zoll C. (2005). Reduplication: Doubling in morphology. Cambridge: Cambridge University Press.

Ittmann, J. (1939/1978). Grammaire du duala (L. A. Boumard, Trans.). Douala: Collège Libermann.

Khisa, W., Wong P., \& Lowe J. B. (2000). Bukusu word list. Filemaker ProTM Database available from present author.

Kimenyi, A. (2002). A tonal grammar of Kinyarwanda: An autosegmental and metrical analysis. Lewiston, N.Y.: E. Mellen Press.

Mateene, K. (1969). Essai de grammaire générative et transformationnelle de la langue nyanga. Kinshasa: Presses Universitaires du Zaïre.

Matondo, M. D. (2003). Tone and prosodic morphology in Kisukuma. Doctoral dissertation, University of California, Los Angeles.

Meinhof, C. (1912). Die Sprache der Duala in Kamerun. Berlin: Dietrich Reimer.

Meinhof, C. (1932). Introduction to the phonology of the Bantu languages (N. J. van Warmelo, Trans., Revised). Berlin: Dietrich Reimer/Ernest Vohsen.

Meeussen, A. E. (1967). Bantu grammatical reconstructions. Africana Linguistica, 3, 81-121. Annales du Musée Royale de l'Afrique Centrale. Série IN-8, Sciences Humaines. N. 121. Tervuren.

Mugane, J. (1997). A paradigmatic grammar of Gikũyũ. Stanford: C.S.L.I.

Mukash-Kalel, T. (1982). Le kanyok: langue bantoue du Zaire: Phonologie, morphologie, syntagmatique. Doctorat de 3ème cycle. INALCO, Paris.

Mutaka, N., \& Hyman L. M. (1990). Syllables and morpheme integrity in Kinande reduplication. Phonology, 7, 73-119.

Nelson, N. (2002). The "prefixing", preference in reduplication. Proceedings of the west coast conference on Formal Linguistics, 21, 320-333.

Ngunga, A. (2000). Phonology and morphology of the Ciyao verb. Stanford: C.S.L.I.

Niepokuj, M. (1997). The development of verbal reduplication in Indo-European. Journal of IndoEuropean Studies Monograph, 24. Washington, D.C.: Insitute for the Study of Man.

Nurse, D. (2007). Did the Proto-Bantu verb have a synthetic or an analytic stucture? In N. C. Kula \& L. Marten (Eds.), Bantu in Bloomsbury: Special Issue on Bantu linguistics. SOAS Working Papers in Linguistics 15 (pp. 239-256). London: University of London.

Odden, D. (1996). Patterns of reduplication in Kikerewe. In D. Dowty et al. (Eds.), Papers in phonology. Working Papers in Linguistics No. 48 (pp. 111-148). Columbus, OH: Ohio State University.

Odden, D. (2001). Re-revisiting reduplication in Kihehe. Handout, Uitø, 18 May 2001.

Odden, D., \& Odden M. (1985). Ordered reduplication in Kihehe. Linguistic Inquiry, 16, 497-504.

Olson, H. S. (1964). The phonology and morphology of Rimi. Hartford: Hartford Seminar Foundation.

Peng, L. (1991). Root and foot in Kikuyu reduplication. Ms. University of Arizona.

Poulos, G. (1990). A linguistic analysis of Venda. Capetown: Via Afrika Ltd.

Rekanga, J.-P. (1989). Essai de grammaire gunu. Doctoral dissertation, Université Libre de Bruxelles. van Sambeek, J. (1955). A Bemba grammar. Capetown: Longmans, Green \& Co.

Sharman, J. C. (1963). Morphology, morphophonology and meaning in the single-word verb forms in Bemba. Doctoral dissertation. University of South Africa.

Sibanda, G. (2004). Verbal phonology and morphology of Ndebele. Doctoral dissertation, University of California, Berkeley.

Stappers, L. (1971). Esquisse de la langue lengola. Africana Linguistica, 5, 257-307.

Stappers, L. (1986a). Kanyok: eine Sprachskizze. Afrikanistische Arbeitspapiere, Sondernummer.

Stappers, L. (1986b). Boma. Eine Sprachskizze. Hamburg: Helmut Buske Verlag.

Steriade, D. (1988). Reduplication and syllable transfer in Sanskrit and elsewhere. Phonology, 5, 73-155.

Tak, J.-Y. (2003). Verbal reduplication in some Bantu languages: A diachronic approach. Eoneohag, 35, 261-292.

Ziervogel, D. (1952). A grammar of Swazi. Johannesberg: Witwatersrand University Press. 